IN THE RED CROSS WORLD

\title{
REPUBLIC OF KOREA
}

It has already been mentioned in the May 1975 issue of International Review that the Florence Nightingale Medal was awarded to three nurses of the Republic of Korea National Red Cross, Mrs. Sung Soon Yew, Mrs. Bok Eum Kim and Miss Catherine M. Mackenzie. ${ }^{1}$

The presentations of this high distinction and its citation were made on 17 October 1975 at a ceremony which took place on the seventieth anniversary of the founding of the National Society, in the presence of representatives of the authorities and senior Red Cross officials. Among those who attended the celebrations were the wife of the Prime Minister of the Republic of Korea; Sir Geoffrey Newman-Morris, Chairman of the International Red Cross Standing Commission and President of the Australian Red Cross; Dr. Ryotaro Azuma, President of the Japanese Red Cross; and representatives of the country's nursing institutions.

\section{LIBYA}

The Libyan Arab Red Crescent Society has kindly sent the International Review an account of its current activities, which we print below. We are very grateful for this contribution, which was preceded by some notes on the Society's history. The Society was founded by decree in 1957, and in 1973 an amended constitution revised the legal status of its activities. A decree issued in the same year set up a general secretariat to carry on humanitarian work at national and at international levels.

\footnotetext{
1 Plate.
} 


\section{Activities of the Libyan Arab Red Crescent Society}

\section{New administrative structure}

The Society now has a general secretariat in Benghazi, and sections in all the principal towns of the Republic. The first three sections were created in 1974 in Tripoli, Sabhā and al-Bidā, their range of action covering the areas of greatest population. There are now 14 sections whose activities cover almost the whole country.

The functions of the general headquarters are briefly:

(a) to create new sections and help them to develop, co-ordinate their work, and provide them with financial and moral support;

(b) to take part in international activities through co-operation with other Societies and with the international institutions of the Red Cross;

(c) to take part in the activities of the secretariat of the Red Crescent and Red Cross Societies of the Arab countries, a regional institution set up in implementation of the Libyan proposal at the Kuwait Conference in February 1974;

(d) to direct, as far as possible, the organization of national and international seminars in the Arab Republic of Libya;

(e) to organize relief actions at local, regional and international level;

(f) to propagate the principles of the Geneva Conventions;

(g) to direct the programmes of blood banks, both mobile and permanent, draw up the working schedule, prepare the campaign for collecting blood and, for this purpose, promote favourable attitudes;

(h) co-ordinate the Society's activities with those of the country's medical services, civilian and military;

(i) to give training in the schools to Junior Red Crescent members who will be motivated by the Red Crescent spirit, the feeling of solidarity which prompts all humanitarian work accomplished under the emblem of the red crescent;

(j) to constitute a women's organization to work in this Red Crescent spirit in the social and cultural spheres.

All the sections' activities are approved by the general secretariat, and vary according to local facilities. It is intended to hold an annual assembly of section presidents to discuss problems connected with the Society's work within the country. 


\section{Activities of the sections}

(a) To provide medical help to the population and thus create a climate of public opinion favourable to the Society;

(b) to operate emergency relief centres in remote areas, on desert roads and on the beaches-these centres were set up by the general secretariat and are now run by the sections;

(c) to organize and direct the programmes of activities and the collection of blood;

(d) to form junior groups in the areas for which they are responsible.

Ever since it was founded the Society has undertaken various types of work and has taken part in aid operations, both national and international. It hopes to continue to carry out its humanitarian mission, overcoming all obstacles, by calling on the help of its members and voluntary workers, on their desire to work together, and on the help and encouragement which the Society has already experienced from governments, from the ICRC and from the League.

\section{Chief activities of the general secretariat at international level}

1. Help to flood victims in Syria in 1974 . The Society sent relief supplies worth 19,000 Libyan dinars to the Syrian Red Crescent Society. ${ }^{1}$

2. At the request of the general secretariat, the Council of Ministers made a gift of one thousand dollars to the Red Crescent Society of Somalia.

3. Active participation by representatives of the Libyan Arab Red Crescent in the Conferences held at Kuwait in 1974 and Riyadh in 1975 , in the two sessions of the Diplomatic Conference in Geneva in 1974 and 1975, and in the World Conference which met in Belgrade in 1975.

\footnotetext{
1 Plate.
} 